\title{
Comparison of PNA Clamping-assisted Fluorescence Melting Curve Analysis and PNA Clamping in Detecting EGFR Mutations in Matched Tumor Tissue, Cell Block, Pleural Effusion and Blood of Lung Cancer Patients With Malignant Pleural Effusion
}

\author{
SANG HOON JEON ${ }^{1 *}$, HYUNG WOO KIM ${ }^{1 *}$, BIT NA KIM ${ }^{1,2}$, NAHYEON KANG ${ }^{1,2}$, CHANG DONG YEO $^{1,2}$, \\ CHAN KWON PARK ${ }^{1,2}$, YOUNG KYOON KIM ${ }^{1}$, YOON HO LEE ${ }^{3}$, TAE-JUNG KIM ${ }^{3}$, KYO YOUNG LEE ${ }^{3}$, \\ SUG HYUNG LEE ${ }^{4}$, JONG Y. PARK ${ }^{5}$, MI SUN PARK ${ }^{6}$, HYEON WOO YIM ${ }^{6}$ and SEUNG JOON KIM ${ }^{1,2}$ \\ ${ }^{1}$ Division of Pulmonology, Department of Internal Medicine, College of Medicine, \\ The Catholic University of Korea, Seoul, Republic of Korea; \\ ${ }^{2}$ The Cancer Research Institute, College of Medicine, The Catholic University of Korea, Seoul, Republic of Korea; \\ ${ }^{3}$ Department of Hospital Pathology, College of Medicine, \\ The Catholic University of Korea, Seoul, Republic of Korea; \\ ${ }^{4}$ Department of Pathology, College of Medicine, The Catholic University of Korea, Seoul, Republic of Korea; \\ ${ }^{5}$ Department of Cancer Epidemiology, Moffitt Cancer Center, Tampa, FL, U.S.A.; \\ ${ }^{6}$ Department of Biostatistics, Clinical Research Coordinating Center, \\ The Catholic University of Korea, Seoul, Republic of Korea
}

\begin{abstract}
Background/Aim: This study compared the efficacy of PANAMutyper ${ }^{T M}$, a novel technology that integrates PNAClamp ${ }^{T M}$ and PANA S-Melting ${ }^{T M}$, and PNAClamp ${ }^{T M}$ alone for the detection of EGFR mutations in lung cancer patients. Materials and Methods: PANAMutyper ${ }^{T M}$ and PNAClamp ${ }^{T M}$ were used to assess the EGFR mutation status in tissue, cell block, pleural effusion, and blood samples of 90 lung cancer patients with malignant pleural effusion. Results: PANAMutyper ${ }^{T M}$ detected more EGFR mutations than
\end{abstract}

This article is freely accessible online.

*These two Authors contributed equally to this study.

Correspondence to: Seung Joon Kim, MD, Ph.D., Division of Pulmonology, Department of Internal Medicine, Seoul St. Mary's Hospital, College of Medicine, The Catholic University of Korea, 222, Banpo-daero, Seocho-gu, Seoul, 06591, Republic of Korea; The Cancer Research Institute, College of Medicine, The Catholic University of Korea, 222, Banpo-daero, Seocho-gu, Seoul, 06591 , Republic of Korea. Tel: +82 222586063, Fax: +82 25993589, e-mail: cmcksj@catholic.ac.kr

Key Words: PNA clamping-assisted fluorescence melting curve analysis, PNA clamping, EGFR mutation, lung cancer, malignant pleural effusion.
PNAClamp ${ }^{T M}$, especially in body fluids (pleural effusion and serum). Patients with additional EGFR mutations detected using PANAMutyper ${ }^{T M}$ had a favorable response to EGFRtyrosine kinase inhibitor (TKI) treatment. Conclusion: The diagnostic performance of PANAMutyper ${ }^{T M}$ was superior to that of PNAClamp ${ }^{T M}$ for the detection of EGFR mutations. It was also better at identifying lung cancer patients with malignant pleural effusion who were likely to benefit from EGFR-TKI treatment.

The use of molecular agents targeting the epidermal growth factor receptor (EGFR) is important in the treatment of advanced non-small cell lung cancer (NSCLC) (1-3). Multiple prospective clinical trials have demonstrated that patients with advanced NSCLC harboring activating mutations in the EGFR gene show improved objective response rates and progression-free survival (PFS) when treated with EGFR tyrosine kinase inhibitors (EGFR-TKIs) (1, 2, 4-8). Therefore, molecular testing for EGFR mutations has become essential for predicting whether a patient will benefit from EGFR-TKI targeted therapy (9).

Previously, we compared peptide nucleic acid (PNA) clamping with direct sequencing for the detection of $E G F R$ and $K-R A S$ mutations. Our results showed that PNA clamping has a better diagnostic performance and higher clinical significance $(10,11)$. 
PANAMutyper ${ }^{\mathrm{TM}} \mathrm{R}$ EGFR is a recently developed kit based on PANA C-Melting ${ }^{\text {TM }}$ technology that takes advantage of both PNAClamp ${ }^{\mathrm{TM}}$ and PANA S-Melting ${ }^{\mathrm{TM}}$. It uses PNA clamping-assisted fluorescence melting curve analysis for a more sensitive detection and genotyping of EGFR mutations.

In the present study, we compared the diagnostic performance of PNA clamping-assisted fluorescence melting curve analysis and PNA clamping alone in matched tumor tissue, cell block, pleural effusion, and blood samples, and also assessed the utility of body fluids for the detection of EGFR mutations. To our knowledge, this is the first study to use PNA clamping-assisted fluorescence melting curve analysis to detect $E G F R$ mutations in pleural effusion samples, and compare this technique with PNA clamping alone.

\section{Materials and Methods}

Patient characteristics. Ninety consecutive patients with primary lung cancer, and malignant pleural effusion at the time of diagnosis, were included in this study. All of the patients underwent diagnostic thoracentesis at the Division of Pulmonology, Seoul St. Mary's Hospital (Seoul, Korea) between September 2008 and December 2016. Malignant pleural effusion was diagnosed by confirmation of malignant cells in pleural tissue, or on cytological examination. If pleural tissue or cytological examination was unavailable, pleural malignancy was diagnosed by an at least ten-fold increase of the upper limit of serum CEA (carcinoembryonic antigen) level with consistent findings of pleural metastasis on chest CT and PET-CT imaging.

All subjects provided written informed consent for the procedure, and the study protocol was approved by the Institutional Review Board of Seoul St. Mary's Hospital, The Catholic University of Korea (IRB approval number: KC16TISI0672).

DNA extraction. DNA was extracted from five 5- $\mu \mathrm{m}$ paraffin sections of tumor tissues and cell blocks. The sections were deparaffinized in xylene and washed in ethanol prior to DNA extraction. For pleural fluid and whole-blood samples, a 5-ml subsample was centrifuged immediately after collection of the liquid specimens; $1 \mathrm{ml}$ of supernatant was used in the DNA analysis. DNA was extracted with a High Pure polymerase chain reaction (PCR) template preparation kit (Roche Applied Science, Mannheim, Germany). After the DNA was eluted in $50 \mu \mathrm{l}$ of elution buffer, its concentration and purity were measured using a NanoDrop ND1000 spectrophotometer (NanoDrop Technologies, Wilmington, DE, USA). Each PNA clamping test was carried out with 40-80 ng (5-10 ng/reaction) of DNA, and each PANAMutyper ${ }^{\mathrm{TM}}$ test with $30-60 \mathrm{ng}$. The extracted DNA was stored at $-20^{\circ} \mathrm{C}$ until it was used.

PNAClamp ${ }^{T M}$. The principle underlying the PNAClamp ${ }^{T M}$ technology is that PNA inhibits the amplification of wild-type DNA by hybridizing to wild-type sequences, so that the mutant DNA is predominantly amplified. It is then detected using a DNA-intercalating dye.

PNAClamp ${ }^{\mathrm{TM}}$ analysis was performed using the PNAClamp ${ }^{\mathrm{TM}}$ EGFR mutation detection kit (Panagene, Daejeon, Korea) following the manufacturer's instructions. Each reaction consisted of $7 \mu \mathrm{l}$ of DNA template, $3 \mu \mathrm{l}$ of each PNA mix, and $10 \mu \mathrm{l}$ of $2 \mathrm{X}$ premix, in a total volume of $20 \mu \mathrm{l}$. The DNA in the reaction was then amplified using the CFX96 real-time PCR instrument (Bio-Rad, Hercules, CA,
Table I. Clinical characteristics of patients.

\begin{tabular}{|c|c|c|}
\hline Variable & Number & Percentage \\
\hline \multicolumn{3}{|l|}{ Gender } \\
\hline Male & 62 & 68.9 \\
\hline Female & 28 & 31.1 \\
\hline \multicolumn{3}{|l|}{ Age (years) } \\
\hline Mean \pm standard deviation & $72 \pm 11$ & \\
\hline \multicolumn{3}{|l|}{ Smoking status } \\
\hline Never smoker & 41 & 45.6 \\
\hline Ex-smoker & 37 & 41.1 \\
\hline Current smoker & 12 & 13.3 \\
\hline \multicolumn{3}{|l|}{ Pathology } \\
\hline Adenocarcinoma & 56 & 62.2 \\
\hline Squamous cell carcinoma & 11 & 12.2 \\
\hline Large cell carcinoma & 3 & 3.3 \\
\hline Sarcomatoid carcinoma & 1 & 1.1 \\
\hline NSCLC NOS & 2 & 2.2 \\
\hline Small cell carcinoma & 17 & 18.9 \\
\hline \multicolumn{3}{|c|}{ Diagnosis of malignant pleural effusion } \\
\hline Pleural biopsy & 7 & 7.8 \\
\hline Pleural fluid cell block only & 61 & 67.8 \\
\hline Clinical diagnosis & 22 & 24.4 \\
\hline Total & 90 & \\
\hline
\end{tabular}

NSCLC NOS: Non-small cell lung cancer not otherwise specified.

USA) with the following thermal program: pre-incubation at $94^{\circ} \mathrm{C}$ for $5 \mathrm{~min}$, and 40 cycles of amplification consisting of $94^{\circ} \mathrm{C}$ for $30 \mathrm{sec}, 70^{\circ} \mathrm{C}$ for $30 \mathrm{sec}, 63^{\circ} \mathrm{C}$ for $30 \mathrm{sec}$, and $72^{\circ} \mathrm{C}$ for $30 \mathrm{sec}$.

The intercalating dye signal was measured stepwise in $63^{\circ} \mathrm{C}$ steps with the threshold cycle $(\mathrm{Ct})$ value of the sample determined based on the fluorescence values measured at each step. $\Delta \mathrm{Ct}$ values were obtained by subtracting the $\mathrm{Ct}$ value of the sample from that of the standard. A $\Delta \mathrm{Ct}$ value $>2.0$ indicated the presence of mutant DNA.

PANAMutyper ${ }^{T M}$. PANAMutyper ${ }^{\mathrm{TM}}$ technology combines PNAClamp ${ }^{\mathrm{TM}}$ with a multiplex detection system using specific PNA detection probes. As with PNAClamp ${ }^{\mathrm{TM}}$, the PNA clamp probe tightly binds only to wild-type DNA sequences and thus suppresses their amplification during PCR. The PNA probe specifically detects target mutant DNA and each mutation is then genotyped by melting peak analysis. As the probe is conjugated with a fluorescent dye and a quencher, the mutant DNA can be visualized.

PANAMutyper ${ }^{\mathrm{TM}}$ analysis was performed using the PANAMutyperTM R EGFR kit (Panagene) following the manufacturer's instructions. Each $25-\mu \mathrm{l}$ reaction consisted of $5 \mu \mathrm{l}$ of DNA template, $19 \mu \mathrm{l}$ of each master mix, and $1 \mu \mathrm{l}$ of Taq polymerase. The DNA was amplified using the CFX96 real-time PCR instrument and the following thermal program: a UDG incubation at $50^{\circ} \mathrm{C}$ for $2 \mathrm{~min}$, pre-incubation at $95^{\circ} \mathrm{C}$ for $15 \mathrm{~min}$, a first round of amplification of 15 cycles $\left(95^{\circ} \mathrm{C}\right.$ for $30 \mathrm{sec}, 70^{\circ} \mathrm{C}$ for $20 \mathrm{sec}, 63^{\circ} \mathrm{C}$ for $\left.1 \mathrm{~min}\right)$, a second round of 35 cycles $\left(95^{\circ} \mathrm{C}\right.$ for $10 \mathrm{sec}, 53^{\circ} \mathrm{C}$ for $20 \mathrm{sec}, 73^{\circ} \mathrm{C}$ for $20 \mathrm{sec}$ ), product denaturation $\left(95^{\circ} \mathrm{C}\right.$ for $\left.15 \mathrm{~min}\right)$, detection probe binding $\left(35^{\circ} \mathrm{C}\right.$ for $\left.5 \mathrm{~min}\right)$, and melting analysis $\left(35-75^{\circ} \mathrm{C}\right.$ at $0.5^{\circ} \mathrm{C}$ increments; detection for $\left.3 \mathrm{sec}\right)$. Four-color fluorescence signals (FAM, HEX, ROX, and Cy5) were measured during the melting analysis. Each sample was then genotyped based on the melting temperature (Tm), determined from 
Table II. Distribution of EGFR mutations detected by PANAMutyper ${ }^{T M}$ and PNAClamp ${ }^{T M}$.

\begin{tabular}{|c|c|c|c|c|c|c|c|c|c|c|}
\hline & \multicolumn{2}{|c|}{ Tissue } & \multicolumn{2}{|c|}{ Cell block } & \multicolumn{2}{|c|}{ Effusion } & \multicolumn{2}{|c|}{ Serum } & \multicolumn{2}{|c|}{ Plasma } \\
\hline & $\begin{array}{c}\text { PANA } \\
\text { Mutyper }^{\mathrm{TM}}\end{array}$ & $\begin{array}{c}\text { PNA } \\
\text { Clamp }^{\mathrm{TM}}\end{array}$ & $\begin{array}{c}\text { PANA } \\
\text { Mutyper }^{\mathrm{TM}}\end{array}$ & $\begin{array}{c}\text { PNA } \\
\text { Clamp }^{\mathrm{TM}}\end{array}$ & $\begin{array}{c}\text { PANA } \\
\text { Mutyper }^{\mathrm{TM}}\end{array}$ & $\begin{array}{c}\text { PNA } \\
\text { Clamp }^{\mathrm{TM}}\end{array}$ & $\begin{array}{c}\text { PANA } \\
\text { Mutyper }^{\mathrm{TM}}\end{array}$ & $\begin{array}{c}\text { PNA } \\
\text { Clamp }^{\text {TM }}\end{array}$ & $\begin{array}{c}\text { PANA } \\
\text { Mutyper }^{\mathrm{TM}}\end{array}$ & $\begin{array}{c}\text { PNA } \\
{ }^{n} \text { Clamp }^{\mathrm{TM}}\end{array}$ \\
\hline \multicolumn{11}{|l|}{ Mutation } \\
\hline Exon 18 G719X & $3(7.5)$ & $1(2.5)$ & - & - & - & - & $1(1.8)$ & - & - & - \\
\hline Exon 18 G719X+Exon 19 del & - & - & - & - & $1(1.1)$ & - & - & - & - & - \\
\hline Exon 18 G719X+Exon 20 S768I & - & - & - & - & $1(1.1)$ & - & - & - & - & - \\
\hline Exon 18 G719X+Exon 21 L858R & $1(2.5)$ & $1(2.5)$ & - & - & $1(1.1)$ & - & - & - & - & - \\
\hline Exon 19 del & $6(15.0)$ & $5(12.5)$ & $10(22.2)$ & $9(20.0)$ & $17(18.9)$ & $16(17.8)$ & $8(14.0)$ & $3(5.3)$ & $1(14.3)$ & - \\
\hline Exon 19 del+Exon 20 T790M & $2(5.0)$ & $1(2.5)$ & $2(4.4)$ & $1(2.2)$ & $2(2.2)$ & $1(1.1)$ & - & - & - & - \\
\hline Exon 20 insertion & - & - & - & - & - & - & $1(1.8)$ & - & - & - \\
\hline Exon $20 \mathrm{~S} 768 \mathrm{I}$ & - & - & $1(2.2)$ & $1(2.2)$ & $1(1.1)$ & - & $1(1.8)$ & - & - & - \\
\hline Exon $20 \mathrm{~T} 790 \mathrm{M}$ & - & - & - & - & - & - & - & - & - & - \\
\hline Exon $21 \mathrm{~L} 858 \mathrm{R}$ & $5(12.5)$ & $7(17.5)$ & $8(17.8)$ & $6(13.3)$ & $10(11.1)$ & $6(6.7)$ & $6(10.5)$ & $4(7.0)$ & $1(14.3)$ & - \\
\hline Exon $21 \mathrm{~L} 858 \mathrm{R}+$ Exon $20 \mathrm{~T} 790 \mathrm{M}$ & $2(5.0)$ & - & - & - & - & - & - & - & - & - \\
\hline Exon 21 L861Q & - & - & - & - & - & - & - & - & - & - \\
\hline Wild-type & $19(47.5)$ & $23(57.5)$ & $24(53.3)$ & $28(62.2)$ & $57(63.3)$ & $67(74.4)$ & $40(70.2)$ & $50(87.7)$ & $5(71.4)$ & $7(100.0)$ \\
\hline Invalid & $2(5.0)$ & $2(5.0)$ & - & - & - & - & - & - & - & - \\
\hline Total & 40 & 40 & 45 & 45 & 90 & 90 & 57 & 57 & 7 & 7 \\
\hline Not measured & 50 & 50 & 45 & 45 & 0 & 0 & 33 & 33 & 83 & 83 \\
\hline
\end{tabular}

Data are presented as $\mathrm{n}(\%)$.

the melting peak of each fluorescent dye. Each sample was assessed according to its specific fluorescence and $\mathrm{Tm}$ range.

Statistical analyses. Demographic data are presented as the means $\pm \mathrm{SD}$, or as the number (n) and percentage. Agreement between the results of PANAMutyper ${ }^{\mathrm{TM}}$ and PNAClamp ${ }^{\mathrm{TM}}$ regarding the EGFR mutation status was confirmed using McNemar's test. The diagnostic performance of each method for detecting mutations in pleural fluids is expressed in terms of the sensitivity, specificity, positive predictive value (PPV), and negative predictive value (NPV), with the mutation status determined in tissue and cell blocks as the reference standard. A common reference standard was used for both of the latter diagnostic methods. A "mutation" in the reference standard was defined as the presence of at least one mutation in a matched tissue or cell block, as identified using either PANAMutyper ${ }^{\mathrm{TM}}$ or PNAClamp ${ }^{\mathrm{TM}}$. The "wild-type" in the reference standard was defined by a failure to detect a mutation with either method. In addition, Cohen's kappa statistic was calculated to compare the agreement between the results from the pleural fluid sample and the reference standard obtained with each method. PFS was defined as the time from the date at which EGFR-TKI treatment was started until the date of disease progression. All significance tests were two sided; A $p$-value $<0.05$ was considered to indicate statistical significance. All statistical analyses were performed using SAS software (ver. 9.4; SAS Institute, Inc., Cary, NC, USA).

\section{Results}

Patient characteristics. Table I shows the demographic characteristics of enrolled patients. The mean age of the 90 patients was 72 years, and 62 (68.9\%) were male. The major histological type of NSCLC was adenocarcinoma (62.2\%). Malignant pleural effusion was proven by pleural biopsy in 7 patients $(7.8 \%)$, and by pleural fluid cell block, including a cytology specimen, in 61 patients $(67.8 \%)$.

Comparison of EGFR mutations detected by PANAMutyper ${ }^{T M}$ and PNAClamp ${ }^{T M}$. Table II provides detailed comparisons of the EGFR mutations detected by PANAMutyper ${ }^{\mathrm{TM}}$ versus PNAClamp $^{\mathrm{TM}}$. In tumor tissue, EGFR mutations were detected by PANAMutyper $^{\mathrm{TM}}$ in 19 of 40 samples $(47.5 \%)$ and by PNAClamp ${ }^{\mathrm{TM}}$ in 15 of 40 samples (37.5\%). In four samples identified as wild-type by PNAClamp ${ }^{\mathrm{TM}}, E G F R$ mutations (two exon 18 G719X, one exon 19 deletion, and one exon 19 deletion plus exon 20 T790M) were detected with the PANAMutyper ${ }^{\mathrm{TM}}$ method. For the other 15 samples identified as mutants, the results of the PNAClamp ${ }^{\mathrm{TM}}$ and PANAMutyper ${ }^{\mathrm{TM}}$ methods were concordant.

In cell blocks, EGFR mutations were identified by PANAMutyper $^{\mathrm{TM}}$ in 21 of 45 samples $(46.7 \%)$ and by PNAClamp $^{\text {TM }}$ in 17 of 45 samples $(37.8 \%)$. In all of the PNAClamp ${ }^{\mathrm{TM}}$ group samples, the results were concordant with those obtained using PANAMutyper ${ }^{\mathrm{TM}}$. Four additional samples were detected as mutants only with the PANAMutyper ${ }^{\mathrm{TM}}$ method (one exon 19 deletion, one exon 19 deletion plus exon 20 T790M, and two exon 21 L858R).

Among the 90 pleural effusion samples, PANAMutyper ${ }^{\mathrm{TM}}$ and PNAClamp ${ }^{\text {TM }}$ identified EGFR mutations in $33(36.7 \%)$ and $23(25.6 \%)$, respectively. In all samples of the PNAClamp ${ }^{\mathrm{TM}}$ group, the results were concordant with those 
Table III. Concordance between PANAMutyper ${ }^{T M}$ and PNAClamp ${ }^{T M}$ for the detection of detailed EGFR mutations.

\begin{tabular}{|c|c|c|c|c|c|c|c|c|c|c|c|}
\hline & \multicolumn{11}{|c|}{ PNAClamp ${ }^{\mathrm{TM}}$} \\
\hline & $\begin{array}{c}\text { Exon } \\
18 \\
\text { G719X }\end{array}$ & $\begin{array}{c}\text { Exon } \\
19 \\
\text { del }\end{array}$ & $\begin{array}{c}\text { Exon } \\
20 \\
\text { S768I }\end{array}$ & $\begin{array}{c}\text { Exon } \\
21 \\
\text { L858R }\end{array}$ & $\begin{array}{c}\text { Exon 18 } \\
\text { G719X } \\
+ \text { Exon 21 } \\
\text { L858R }\end{array}$ & $\begin{array}{c}\text { Exon } \\
19 \text { del } \\
+ \text { Exon } 20 \\
\text { T790M }\end{array}$ & $\begin{array}{l}\text { Wild } \\
\text { type/ } \\
\text { Invalid }\end{array}$ & Total & $\begin{array}{c}\mathrm{K} \\
\text { coefficient } \\
(95 \% \mathrm{CI})\end{array}$ & $\begin{array}{c}\text { Overall } \\
\text { agreement } \\
(95 \% \mathrm{CI})\end{array}$ & $\begin{array}{c}\text { McNemar's } \\
\text { test } \\
p \text {-Value* }\end{array}$ \\
\hline \multicolumn{12}{|l|}{ PANAMutyper ${ }^{\mathrm{TM}}$} \\
\hline \multicolumn{12}{|l|}{ Tissue } \\
\hline Exon 18 G719X & 1 & - & - & - & - & - & 2 & 3 & $\begin{array}{c}0.72 \\
(0.55-0.90)\end{array}$ & $\begin{array}{c}0.83 \\
(0.67-0.93)\end{array}$ & 0.046 \\
\hline Exon 19 del & - & 4 & - & - & - & - & 2 & 6 & & & \\
\hline Exon $21 \mathrm{~L} 858 \mathrm{R}$ & - & - & - & 5 & - & - & - & 5 & & & \\
\hline Exon 18 G719X+Exon 21 L858R & - & - & - & - & 1 & - & - & 1 & & & \\
\hline Exon 19 del+Exon 20 T790M & - & 1 & - & - & - & 1 & - & 2 & & & \\
\hline Exon $21 \mathrm{~L} 858 \mathrm{R}+$ Exon $20 \mathrm{~T} 790 \mathrm{M}$ & - & - & - & 2 & - & - & - & 2 & & & \\
\hline Wild-type/Invalid & - & - & - & - & - & - & 21 & 21 & & & \\
\hline Total & 1 & 5 & - & 7 & 1 & 1 & 25 & 40 & & & \\
\hline \multicolumn{12}{|l|}{ Cell block } \\
\hline Exon 19 del & - & 9 & - & - & - & - & 1 & 10 & $\begin{array}{c}0.85 \\
(0.71-0.99)\end{array}$ & $\begin{array}{c}0.91 \\
(0.79-0.98)\end{array}$ & 0.046 \\
\hline Exon $20 \mathrm{~S} 768 \mathrm{I}$ & - & - & 1 & - & - & - & 0 & 1 & & & \\
\hline Exon $21 \mathrm{~L} 858 \mathrm{R}$ & - & - & - & 6 & - & - & 2 & 8 & & & \\
\hline Exon 19 del+Exon 20 T790M & - & - & - & - & - & 1 & 1 & 2 & & & \\
\hline Wild-type/Invalid & - & - & - & - & - & - & 24 & 24 & & & \\
\hline Total & - & 9 & 1 & 6 & - & 1 & 28 & 45 & & & \\
\hline \multicolumn{12}{|l|}{ Effusion } \\
\hline Exon 19 del & - & 14 & - & - & - & - & 3 & 17 & $\begin{array}{c}0.73 \\
(0.59-0.86)\end{array}$ & $\begin{array}{c}0.87 \\
(0.78-0.93)\end{array}$ & 0.002 \\
\hline Exon $20 \mathrm{~S} 768 \mathrm{I}$ & - & - & - & - & - & - & 1 & 1 & & & \\
\hline Exon $21 \mathrm{~L} 858 \mathrm{R}$ & - & - & - & 6 & - & - & 4 & 10 & & & \\
\hline Exon 18 G719X+Exon 21 L858R & - & - & - & - & - & - & 1 & 1 & & & \\
\hline Exon 18 G719X+Exon 19 del & - & 1 & - & - & - & - & - & 1 & & & \\
\hline Exon $18 \mathrm{G} 719 \mathrm{X}+$ Exon $20 \mathrm{~S} 768 \mathrm{I}$ & - & - & - & - & - & - & 1 & 1 & & & \\
\hline Exon 18 G719X+Exon 19 del & - & 1 & - & - & - & 1 & - & 2 & & & \\
\hline Wild-type/Invalid & - & - & - & - & - & - & 57 & 57 & & & \\
\hline Total & - & 16 & - & 6 & - & 1 & 67 & 90 & & & \\
\hline \multicolumn{12}{|l|}{ Serum } \\
\hline Exon 18 G719X & - & - & - & - & - & - & 1 & 1 & $\begin{array}{c}0.53 \\
(0.29-0.77)\end{array}$ & $\begin{array}{c}0.82 \\
(0.70-0.91)\end{array}$ & 0.002 \\
\hline Exon 19 del & - & 3 & - & - & - & - & 5 & 8 & & & \\
\hline Exon 20 ins & - & - & - & - & - & - & 1 & 1 & & & \\
\hline Exon $20 \mathrm{~S} 768 \mathrm{I}$ & - & - & - & - & - & - & 1 & 1 & & & \\
\hline Exon $21 \mathrm{~L} 858 \mathrm{R}$ & - & - & - & 4 & - & - & 2 & 6 & & & \\
\hline Wild-type/Invalid & - & - & - & - & - & - & 40 & 40 & & & \\
\hline Total & - & 3 & - & 4 & - & - & 50 & 57 & & & \\
\hline \multicolumn{12}{|l|}{ Plasma } \\
\hline Exon 19 del & - & - & - & - & - & - & 1 & 1 & - & $\begin{array}{c}0.71 \\
(0.29-0.96)\end{array}$ & 0.500 \\
\hline Exon $21 \mathrm{~L} 858 \mathrm{R}$ & - & - & - & - & - & - & 1 & 1 & & & \\
\hline Wild-type/Invalid & - & - & - & - & - & - & 5 & 5 & & & \\
\hline Total & - & - & - & - & - & - & 7 & 7 & & & \\
\hline
\end{tabular}

*All patients were categorized into two groups: mutant/wild-type.

obtained with PANAMutyper ${ }^{\mathrm{TM}}$. In 10 samples identified as wild-type by PNAClamp ${ }^{\mathrm{TM}}, E G F R$ mutations (three exon 19 deletions, four exon 21 L858R, one exon 20 S768I, one exon 18 G719X plus exon 20 S768I, and one exon 18 G719X plus exon 21 L858R) were detected with PANAMutyper ${ }^{\mathrm{TM}}$. In two samples identified by PNAClamp ${ }^{\mathrm{TM}}$ as carrying only an exon 19 deletion, PANAMutyper ${ }^{\mathrm{TM}}$ detected additional EGFR mutations (one exon 18 G719X and one exon 20 T790M). 
Table IV. Diagnostic performance of two methods in pleural effusion compared with matched tissue or cell block.

\begin{tabular}{|c|c|c|c|c|c|c|c|}
\hline Mutation & Wild-type & Total & $\begin{array}{l}\text { Sensitivity } \\
(95 \% \mathrm{CI})^{*}\end{array}$ & $\begin{array}{c}\text { Specificity } \\
(95 \% \mathrm{CI})\end{array}$ & $\begin{array}{c}\text { PPV } \\
(95 \% \mathrm{CI})\end{array}$ & $\begin{array}{c}\mathrm{NPV} \\
(95 \% \mathrm{CI})\end{array}$ & $\begin{array}{c}\text { K coefficient } \\
(95 \% \mathrm{CI})\end{array}$ \\
\hline
\end{tabular}

Reference standard: Tissue or cell block

\begin{tabular}{lcccccccc}
$\begin{array}{l}\text { Effusion of PANAMutyper }{ }^{\mathrm{TM}} \\
\quad \text { Mutation }\end{array}$ & 26 & 0 & 26 & 83.87 & 100.00 & 100.00 & 88.10 & 0.85 \\
$\quad \begin{array}{l}\text { Wild-type } \\
\begin{array}{l}\text { Effusion of PNAClamp } \\
\quad \text { TM }\end{array}\end{array}$ & 5 & 37 & 42 & $(66.27-94.55)$ & $(90.51-100.00)$ & $(86.77-100.00)$ & $(74.37-96.02)$ & $(0.72-0.98)$ \\
$\quad \begin{array}{l}\text { Mutation } \\
\text { Wild-type }\end{array}$ & 19 & 0 & 19 & 61.29 & 100.00 & 100.00 & 75.51 & 0.63 \\
\hline
\end{tabular}

* $p$-Value of McNemar's test for comparing sensitivities $=0.016$.

PANAMutyper ${ }^{\mathrm{TM}}$ detected EGFR mutations in 17 out of $57(29.8 \%)$, and PNAClamp ${ }^{\mathrm{TM}}$ in 7 out of $57(12.3 \%)$, serum samples. In the PNAClamp ${ }^{\mathrm{TM}}$ group, the EGFR mutation status results were concordant with those obtained using PANAMutyper ${ }^{\mathrm{TM}}$. However, 10 additional mutations were detected only by PANAMutyper ${ }^{\mathrm{TM}}$ (one exon 18 G719X, five exon 19 deletions, one exon 20 insertion, one exon 20 S768I, and two exon 21 L858R).

Among the seven plasma samples, mutations (one exon 19 deletion and one exon 21 L858R) were identified in two using PANAMutyper ${ }^{\mathrm{TM}}$, whereas using PNAClamp ${ }^{\mathrm{TM}}$ all samples were identified as wild-type.

Concordance of PANAMutyper ${ }^{T M}$ and PNAClamp ${ }^{T M}$. The degree of diagnostic concordance between PANAMutyper ${ }^{\mathrm{TM}}$ and PNAClamp ${ }^{\mathrm{TM}}$ in tissue, cell block, effusion, serum, and plasma samples is presented in Table III. Concordant cases were those in which one diagnostic method detected a mutation, and the same, plus additional mutations were detected by the other. Discordance between the two diagnostic methods occurred in tissue $(p=0.046)$, cell block $(p=0.046)$, effusion $(p=0.002)$, and serum $(p=0.002)$ samples. In all these cases, the discordance resulted from an additional $E G F R$ mutation detected by PANAMutyper ${ }^{\mathrm{TM}}$. PNAClamp ${ }^{\mathrm{TM}}$ detected no additional mutations.

Diagnostic performance of the two methods in detecting EGFR mutations in pleural effusion. Compared with the results obtained with a matched tissue or cell block (reference standard) sample, PANAMutyper ${ }^{\mathrm{TM}}$ detected $E G F R$ mutations in pleural effusion samples with an $83.87 \%$ sensitivity, $100 \%$ specificity, a PPV of $100 \%$, and an NPV of $88.10 \%$. The corresponding values for PNAClamp $^{\mathrm{TM}}$ were $61.29 \%, 100 \%, 100 \%$, and $75.51 \%$ (Table IV). Thus, in the test using pleural effusion samples, the sensitivity of PANAMutyper ${ }^{\mathrm{TM}}$ was significantly better $(p=0.016)$.
Comparison of the EGFR-TKI response according to mutations detected by PANAMutyper ${ }^{T M}$ and PNAClamp ${ }^{T M}$. Of the 90 patients enrolled in the present study, 26 underwent EGFR-TKI treatment. The mutation status of their disease, as well as their response to EGFR-TKI treatment, are presented in Table V. Compared with patients whose disease was not characterized by an EGFR mutation (patients 5-7), a favorable response, including a longer PFS, occurred in most of the patients in whom EGFR mutations were detected in any sample by PANAMutyper ${ }^{\mathrm{TM}}$ and PNAClamp ${ }^{\mathrm{TM}}$. Twenty of these patients had a partial response, one had stable disease, and two had no evaluable disease.

In 15 of these 26 patients, PANAMutyper ${ }^{\mathrm{TM}}$ detected additional mutations in any sample that were not detected by PNAClamp ${ }^{\mathrm{TM}}$. After EGFR-TKI treatment, 13 of these patients had a partial response, one had stable disease, and one had non-evaluable disease.

In patient 3, who had an invalid or wild-type status in the tissue, cell block, and effusion samples, the EGFR-activating mutation L858R in exon 21 was detected in the serum, but only by PANAMutyper ${ }^{\mathrm{TM}}$. This patient had a partial response to EGFR-TKI treatment, which could not be prescribed for a longer period due to the development of interstitial lung disease. In patient 8 , in whom the EGFR mutation status could not be determined in the tumor tissue or cell block, an $E G F R$-activating (exon $19 \mathrm{del}$ ) mutation was detected by PANAMutyper ${ }^{\mathrm{TM}}$ in pleural effusion and serum. The PFS of this patient was 299 days (Figure 1). Three patients $(9,16$, 24) in whom an exon 20 T790M mutation was detected had a partial response to EGFR-TKI treatment.

\section{Discussion}

This study was designed to compare the diagnostic efficiency of PANAMutyper ${ }^{\mathrm{TM}}$ and PNAClamp ${ }^{\mathrm{TM}}$ in the detection of EGFR mutations in tissue, cell block, pleural effusion, and blood samples. There was a high concordance between the two methods, although in all sample types more $E G F R$ 

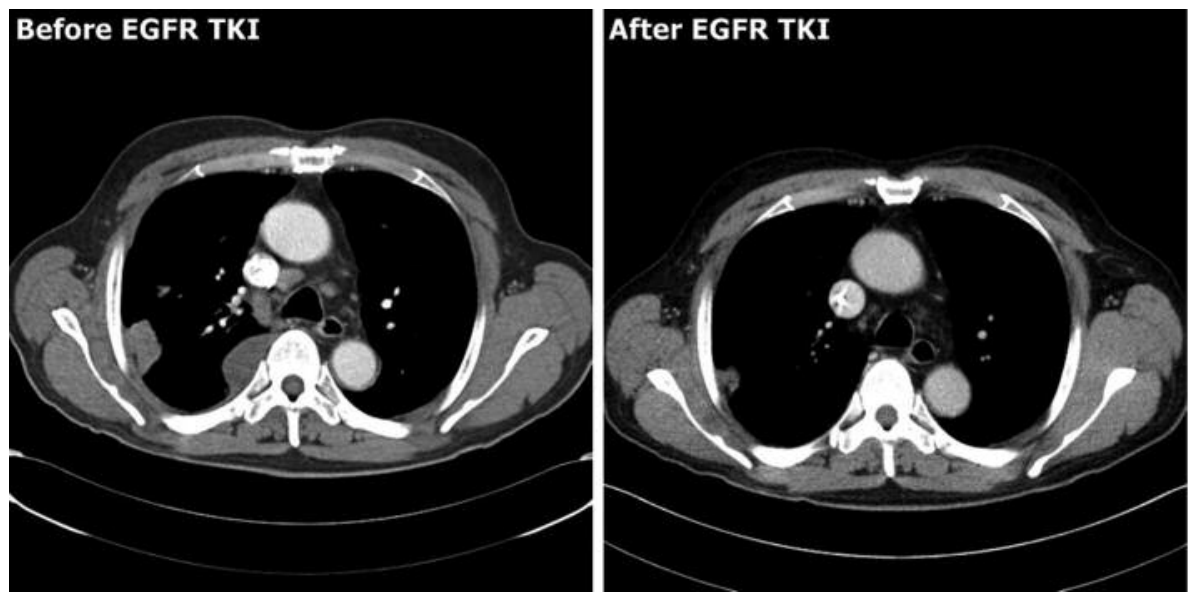

Figure 1. Representative chest CT images of a lung cancer patient (case 8) who received EGFR-TKI treatment for 2 months. The EGFR exon 19 deletion was detected in pleural effusion and serum samples only by PANAMutyper ${ }^{T M}$.

mutations were detected with PANAMutyper ${ }^{\mathrm{TM}}$ than with PNAClamp $^{\mathrm{TM}}$. Interestingly, the EGFR mutations additionally detected with PANAMutyper ${ }^{\mathrm{TM}}$ were more prominent in pleural effusion and serum samples than in tissue and cell block samples. Among the 15 patients with EGFR mutations additionally detected in any sample by PANAMutyper ${ }^{\mathrm{TM}}, 14$ patients had a favorable response to EGFR-TKI treatment; in the other patient the response was not evaluable. These findings suggested the greater efficacy of PANAMutyper ${ }^{\mathrm{TM}}$ compared to PNAClamp ${ }^{\mathrm{TM}}$ in identifying patients likely to benefit from EGFR-TKI treatment.

PNA is a synthetic DNA analog that binds strongly to its complementary DNA sequence (12). In PNA clamping PCR, which uses a PNA oligomer, binding of the PNA to wild-type $E G F R$ DNA enables rapid detection of EGFR mutations with high sensitivity (13). The wild-type DNA cannot be amplified by the tightly bound PNA probe and the mutated DNA sequences are selectively PCR-amplified. PNAClamp $^{\mathrm{TM}}$ allows the efficient detection of somatic mutations, such as those in the EGFR and $K$-RAS genes. In PANA S-Melting ${ }^{\mathrm{TM}}$, multiplex melting curve analysis is carried out using a fluorescently labeled PNA probe. The technique is based on the change in the fluorescence signal following thermal denaturation of the sample (Tm shift). Thus, PANA S-Melting ${ }^{\mathrm{TM}}$ is a powerful tool for the detection of mutations for both screening and genotyping purposes.

By integrating PNAClamp ${ }^{\mathrm{TM}}$ and PANA S-Melting ${ }^{\mathrm{TM}}$, PANA C-Melting ${ }^{\mathrm{TM}}$ takes advantage of both technologies. It is able not only to detect mutations, present at low levels, with high sensitivity, but also to genotype multiple mutations simultaneously by taking advantage of the changes in Tm that are due to sequence changes in the target gene. PANAMutyper $^{\mathrm{TM}} \mathrm{R}$ EGFR using PANA C-Melting ${ }^{\mathrm{TM}}$ technology can segregate mutant from wild-type genes with a sensitivity of $0.1-0.01 \%$ (14).

The use of molecular biomarkers in body fluids, such as pleural fluid, serum, and plasma, may be clinically helpful for predicting therapeutic response to treatments such as EGFR-TKI. Among the advantages of using body fluids are their easy accessibility, the non-invasive means used to collect them, the option of repeated sampling, and their availability when tumor tissues cannot be obtained. However, there are insufficient data to evaluate the utility of body fluids in determining the overall mutation rates and EGFR-TKI responses.

Malignant pleural effusion is a common complication of lung cancer, with an incidence at the time of diagnosis of 8$15 \%$ (15). Pleural effusion can be sampled relatively easily in NSCLC patients and is particularly useful in those with inoperable disease. The presence of tumor cells in pleural fluid makes it a good source of tumor DNA, as even a small amount of soluble DNA in cell-free pleural fluid is sufficient for most molecular analyses (16-18). The present study demonstrated the good diagnostic performance of pleural effusion samples in the detection of EGFR mutations. Of the technologies tested, the sensitivity of PANAMutyper ${ }^{\mathrm{TM}}$ was significantly higher than that of PNAClamp ${ }^{\mathrm{TM}}$.

The yield of malignant cells in a malignant effusion sample is approximately $60 \%$ (19), but this is not a limitation with the novel methods used in this and other studies with respect to detecting EGFR mutations in cell-free DNA. For example, the PPV and NPV of cell-free malignant pleural effusion analyzed using the amplified refractory mutation system (ARMS) was $100 \%$ and $71.4 \%$, respectively, compared to matched tissue samples (20). Chen et al. (21) showed that the sensitivity of PNA-sequencing (63.2\%) and RNA sequencing (65.4\%) in the 


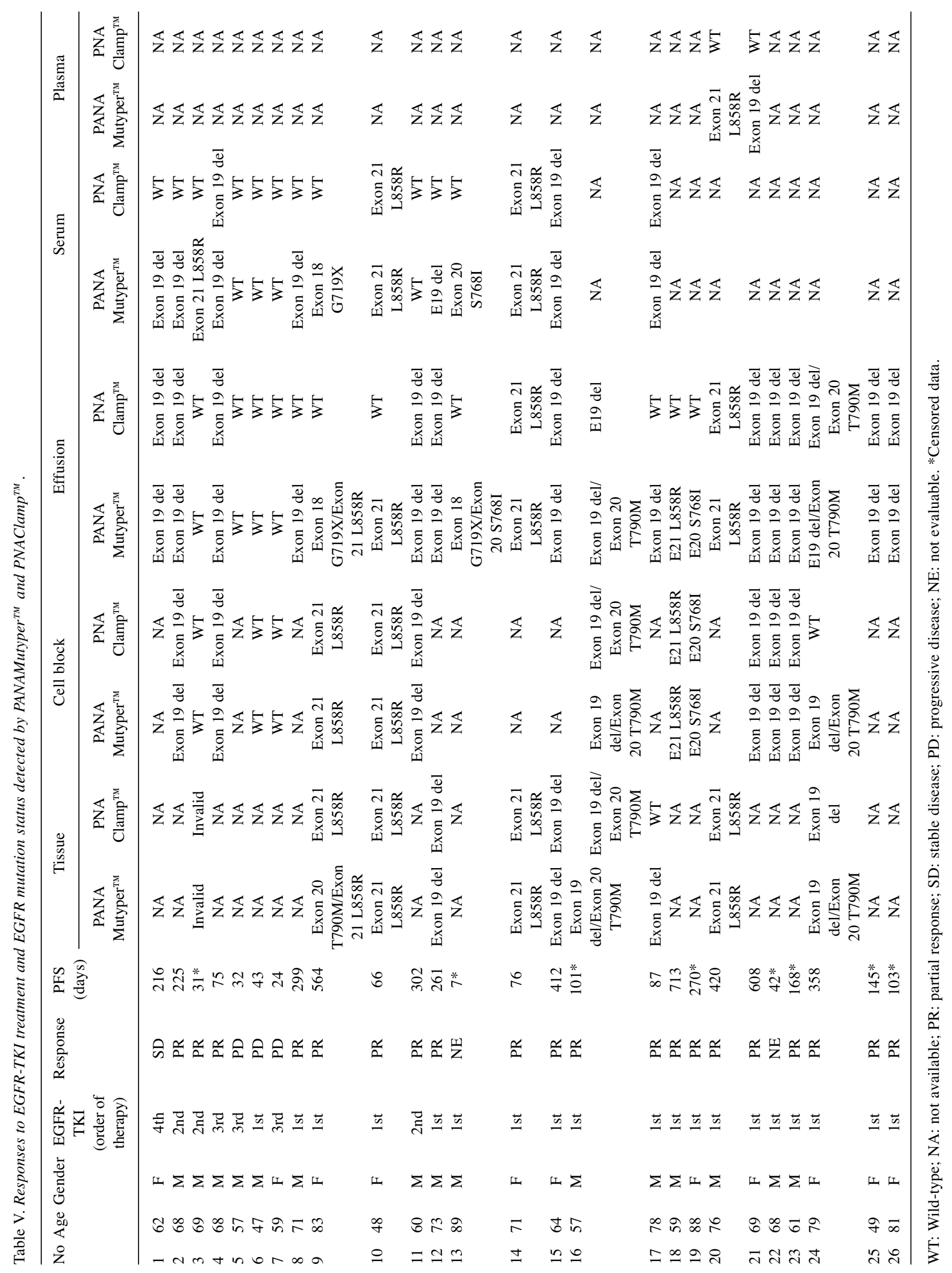


analysis of malignant pleural effusion was better than that of direct sequencing (56.4\%). In our study, PANAMutyper ${ }^{\mathrm{TM}}$ had good diagnostic performance, shown by a sensitivity of $83.87 \%$, specificity of $100.00 \%$, PPV of $100.00 \%$, and NPV of $88.10 \%$. These values were higher than those reported in two previous studies $(20,21)$.

$E G F R$ mutation status is typically assessed by direct sequencing of exons 18 to 21 of the EGFR gene. However, more sensitive methods are now available $(22,23)$, as we have previously shown in a study comparing PNA clamping with direct sequencing (10).

Despite the encouraging results, our study had several limitations. First, the number of patients was small. Second, the tumor tissue and cell block samples were not matched in number, because after routine pathological examination some specimens were insufficient. Third, there were too few plasma samples to allow analysis of the clinical relevance of plasma with respect to EGFR mutation detection using the methods described herein. However, to the best of our knowledge, this is the first study to evaluate the diagnostic performance of PNA clamping-assisted fluorescence melting curve analysis, and to compare its efficacy in different samples, including pleural fluids.

In conclusion, our results demonstrate the good diagnostic performance of PANAMutyper ${ }^{\mathrm{TM}}$ and its superiority compared to PNAClamp ${ }^{\mathrm{TM}}$ in the analysis of body fluid samples. Nonetheless, there was a high concordance between the results obtained with the two methods. More sensitive and accurate detection of EGFR mutations would allow for identification of a higher number of lung cancer patients likely to benefit from EGFR-TKI treatment, and therefore the design of a more personalized therapeutic approach for these patients.

\section{Conflicts of Interest}

The Authors declare no conflicts of interest regarding this study.

\section{Authors' Contributions}

Conception and design: Sang Hoon Jeon, Hyung Woo Kim, Seung Joon Kim. Development of methodology: Bit Na Kim, Nahyeon Kang.Acquisition of data: Chang Dong Yeo, Chan Kwon Park. Analysis and interpretation of data (e.g., statistical analysis, biostatistics, computational analysis): Mi Sun Park, Hyeon Woo Yim. Writing, review, and/or revision of the manuscript: Sang Hoon Jeon, Hyung Woo Kim, Seung Joon Kim, Jong Y. Park. Administrative, technical, or material support: Yoon Ho Lee, TaeJung Kim, Kyo Young Lee, Young Kyoon Kim, Sug Hyung Lee. Study supervision: Seung Joon Kim.

\section{Acknowledgements}

This work was supported by a National Research Foundation of Korea (NRF) grant funded by the Korea government (MSIP) (No. 2014R1A2A1A11052422). The statistical consultation was supported by a Grant of the Korea Health Technology R\&D Project through the Korea Health Industry Development Institute (KHIDI), funded by the Ministry of Health \& Welfare, Republic of Korea (grant number: HI14C1062).

\section{References}

1 Maemondo M, Inoue A, Kobayashi K, Sugawara S, Oizumi S, Isobe $\mathrm{H}$, Gemma A, Harada M, Yoshizawa H, Kinoshita I, Fujita Y, Okinaga S, Hirano H, Yoshimori K, Harada T, Ogura T, Ando M, Miyazawa H, Tanaka T, Saijo Y, Hagiwara K, Morita S and Nukiwa T: Gefitinib or chemotherapy for non-small-cell lung cancer with mutated EGFR. N Engl J Med 362: 2380-2388, 2010.

2 Zhou C, Wu YL, Chen G, Feng J, Liu XQ, Wang C, Zhang S, Wang J, Zhou S, Ren S, Lu S, Zhang L, Hu C, Hu C, Luo Y, Chen L, Ye M, Huang J, Zhi X, Zhang Y, Xiu Q, Ma J, Zhang L and You C: Erlotinib versus chemotherapy as first-line treatment for patients with advanced EGFR mutation-positive non-smallcell lung cancer (OPTIMAL, CTONG-0802): a multicentre, open-label, randomised, phase 3 study. Lancet Oncol 12: 735$742,2011$.

3 Kim HC, Jung CY, Cho DG, Jeon JH, Lee JE, Ahn JS, Kim SJ, Kim Y, Kim YC, Kim JE, Lee B, Won YJ and Choi CM: Clinical characteristics and prognostic factors of lung cancer in Korea: A Pilot Study of Data from the Korean Nationwide Lung Cancer Registry. Tuberc Respir Dis (Seoul), 2018. doi: 10.4046/ trd.2017.0128. [Epub ahead of print]

4 Kwon BS, Park JH, Kim WS, Song JS, Choi CM, Rho JK and Lee JC: Predictive Factors for Switched EGFR-TKI retreatment in patients with EGFR-mutant non-small cell lung cancer. Tuberc Respir Dis (Seoul) 80: 187-193, 2017.

5 Kogure Y, Shigematsu F, Oki M and Saka H: T790M Correlates with longer progression-free survival in non-small cell lung carcinomas harboring EGFR mutations. In Vivo 32: 1199-1204, 2018.

6 Masuhiro K, Shiroyama T, Suzuki H, Takata SO, Nasu S, Takada $\mathrm{H}$, Morita S, Tanaka A, Morishita N, Okamoto N and Hirashima $\mathrm{T}$ : Impact of pleural effusion on outcomes of patients receiving osimertinib for NSCLC harboring EGFR T790M. Anticancer Res 38: 3567-3571, 2018.

7 Baek MY, Ahn HK, Park KR, Park HS, Kang SM, Park I, Kim YS, Hong J, Sym SJ, Park J, Lee JH, Shin DB and Cho EK: Epidermal growth factor receptor mutation and pattern of brain metastasis in patients with non-small cell lung cancer. Korean J Intern Med 33: 168-175, 2018.

8 Borghetti P, Bonu ML, Roca E, Pedretti S, Salah E, Baiguini A, Greco D, Triggiani L, Maddalo M, Levra NG, Alongi F, Magrini SM and Buglione M: Radiotherapy and tyrosine kinase inhibitors in stage IV non-small cell lung cancer: real-life experience. In Vivo 32: 159-164, 2018.

9 Choi YW and Choi JH: Does the efficacy of epidermal growth factor receptor (EGFR) tyrosine kinase inhibitor differ according to the type of EGFR mutation in non-small cell lung cancer? Korean J Intern Med 32: 422-428, 2017.

10 Yeo CD, Kim JW, Kim KH, Ha JH, Rhee CK, Kim SJ, Kim YK, Park CK, Lee SH, Park MS and Yim HW: Detection and comparison of EGFR mutations in matched tumor tissues, cell blocks, pleural effusions, and sera from patients with NSCLC with malignant pleural effusion, by PNA clamping and direct sequencing. Lung Cancer 81: 207-212, 2013. 
11 Kang JY, Park CK, Yeo CD, Lee HY, Rhee CK, Kim SJ, Kim SC, Kim YK, Park MS and Yim HW: Comparison of PNA clamping and direct sequencing for detecting KRAS mutations in matched tumour tissue, cell block, pleural effusion and serum from patients with malignant pleural effusion. Respirology 20: 138-146, 2015.

12 Wittung P, Nielsen PE, Buchardt O, Egholm M and Norden B: DNA-like double helix formed by peptide nucleic acid. Nature 368: 561-563, 1994.

13 Kim HJ, Lee KY, Kim YC, Kim KS, Lee SY, Jang TW, Lee MK, Shin KC, Lee GH, Lee JC, Lee JE and Kim SY: Detection and comparison of peptide nucleic acid-mediated real-time polymerase chain reaction clamping and direct gene sequencing for epidermal growth factor receptor mutations in patients with non-small cell lung cancer. Lung Cancer 75: 321-325, 2012.

14 Han JY, Choi JJ, Kim JY, Han YL and Lee GK: PNA clampingassisted fluorescence melting curve analysis for detecting EGFR and KRAS mutations in the circulating tumor DNA of patients with advanced non-small cell lung cancer. BMC Cancer 16: 627, 2016.

15 Antony VB, Loddenkemper R, Astoul P, Boutin C, Goldstraw P, Hott J, Rodriguez Panadero F and Sahn SA: Management of malignant pleural effusions. Eur Respir J 18: 402-419, 2001.

16 Soh J, Toyooka S, Aoe K, Asano H, Ichihara S, Katayama H, Hiraki A, Kiura K, Aoe M, Sano Y, Sugi K, Shimizu N and Date $\mathrm{H}$ : Usefulness of EGFR mutation screening in pleural fluid to predict the clinical outcome of gefitinib treated patients with lung cancer. Int J Cancer 119: 2353-2358, 2006.

17 Zhang X, Zhao Y, Wang M, Yap WS and Chang AY: Detection and comparison of epidermal growth factor receptor mutations in cells and fluid of malignant pleural effusion in non-small cell lung cancer. Lung Cancer 60: 175-182, 2008.
18 Kawahara A, Azuma K, Sumi A, Taira T, Nakashima K, Aikawa E, Abe H, Yamaguchi T, Takamori S, Akiba J and Kage M: Identification of non-small-cell lung cancer with activating EGFR mutations in malignant effusion and cerebrospinal fluid: rapid and sensitive detection of exon 19 deletion E746-A750 and exon 21 L858R mutation by immunocytochemistry. Lung Cancer 74: 35-40, 2011.

19 Maskell NA and Butland RJ: BTS guidelines for the investigation of a unilateral pleural effusion in adults. Thorax 58: ii8-17, 2003.

20 Liu X, Lu Y, Zhu G, Lei Y, Zheng L, Qin H, Tang C, Ellison G, McCormack R and Ji Q: The diagnostic accuracy of pleural effusion and plasma samples versus tumour tissue for detection of EGFR mutation in patients with advanced non-small cell lung cancer: comparison of methodologies. J Clin Pathol 66: 10651069, 2013.

21 Chen YL, Lee CT, Lu CC, Yang SC, Chen WL, Lee YC, Yang $\mathrm{CH}$, Peng SL, Su WC, Chow NH and Ho CL: Epidermal Growth Factor Receptor Mutation and Anaplastic Lymphoma Kinase Gene Fusion: Detection in malignant pleural effusion by RNA or PNA analysis. PLoS One 11: e0158125, 2016.

$22 \mathrm{Li} \mathrm{T}$, Kung HJ, Mack PC and Gandara DR: Genotyping and genomic profiling of non-small-cell lung cancer: implications for current and future therapies. J Clin Oncol 31: 1039-1049, 2013.

23 Matsumoto $\mathrm{N}$, Kumasaka A, Ando $\mathrm{T}$ and Komiyama K: Detection of EGFR gene mutation by mutation-oriented LAMP method. Anticancer Res 38: 2093-2099, 2018.

Received December 9, 2018

Revised December 30, 2018

Accepted December 31, 2018 